\title{
Genome-scale antibody responses in TB
}

\author{
Maria L Gennaro \\ From Immunodiagnosis of Tuberculosis: New Questions, New Tools \\ Virginia, VA, USA. 21-23 September 2008
}

High-throughput methods have made it possible to generate microarrays carrying all $\sim 4,000$ proteins of MMycobacterium tuberculosis (M.tb). With this platform, large numbers of individual sera from infected humans and animals can be tested for antibody detection. Preliminary results of probing $M$. $t b$ proteome microarrays with sera collected under a uniform study protocol at various sites worldwide from $>500$ pulmonary TB suspects who received a final diagnosis of active TB or non-TB-disease (NTBD) showed that approximately 500 M.tb proteins reacted with at least one serum, while the rest of the proteome reacted to none. Thus the immunoproteome of $M . t b$ is approximately one-tenth the size of the total proteome. It was also found that, among the $\sim 500$ reactive proteins, only a fraction reacted differentially to active $T B$ sera versus NTBD sera. It is intuitive that serodiagnostic antigens belong to this antigen subset. Additionally, no obvious pattern of reactivity was observed among active TB sera. This result indicates that, within the pool of seroreactive antigens, target recognition greatly varies from individual to individual. We also explored the association between proteome-scale antibody responses and clinical and demographic covariates, such as patients' age and gender, country of origin, bacillary burden (expressed as sputum smear grade), HIV status, etc. In particular, we found that the antibody response to some antigens positively correlated with sputum smear grade, while the response to others was independent of smear grade. The previously reported positive correlation between reactivity to the $38 \mathrm{kDa}$ antigen and bacillary burden supports the proteome-wide results. We also observed that, while antibody profiles varied among sera, antigens exhibiting the highest differential ability were recognized across geographical sites. Thus, it should be possible to identify

Correspondence: gennarma@umdnj.edu

Public Health Research Institute, University of Medicine and Dentistry of New Jersey, Newark, New Jersey, USA serodiagnostic antigens that can be utilized worldwide. As previously reported, HIV co-infection dampened the antibody response. Moreover, results of protein class analysis showed that reactivity to the glyoxylate bypass proteins was associated with active TB. This metabolic pathway is essential for $M . t b$ growth and survival in mice, and is up-regulated in tubercle bacilli found in human sputa. Thus, the analysis of antibody responses at the proteome scale can be informative of the biology of tubercle bacilli in the human host. In addition, proteome microarray probing with sera from experimentally infected macaques showed that antibody responses vary with progression to disease, supporting the possibility that disease progression can be monitored by serology.

Published: 17 December 2010

doi:10.1186/1753-6561-4-S3-09

Cite this article as: Gennaro: Genome-scale antibody responses in TB. BMC Proceedings 2010 4(Suppl 3):09.

Submit your next manuscript to BioMed Central and take full advantage of:

- Convenient online submission

- Thorough peer review

- No space constraints or color figure charges

- Immediate publication on acceptance

- Inclusion in PubMed, CAS, Scopus and Google Scholar

- Research which is freely available for redistribution

Submit your manuscript at www.biomedcentral.com/submit
Biomed Central 